\title{
RELATIONSHIP OF ACADEMIC SELF-MANAGEMENT AND ACADEMIC ANXIETY TOWARDS ACADEMIC ACHIEVEMENT OF FIRST YEAR STUDENTS IN INSTITUT TEKNOLOGI BANDUNG
}

\author{
Rika Afifah, Aria Bayu Pangestu
}

Institut Teknologi Bandung (ITB) Jawa Barat, Indonesia

Email: rika_afifah@sbm-itb.ac.id, aria.bayu@sbm-itb.ac.id

\section{Abstract}

Previous study has shown that academic anxiety is associated to academic selfmanagement, and it also has a detrimental impact on students' academic achievement. The purpose of this study is to determine the link between academic self-management and academic anxiety towards academic achievement in first-year students at Institut Teknologi Bandung using quantitative approach on 111 firstyear students. According to the findings of the regression analysis, academic selfmanagement and academic anxiety accounted for $21.4 \%$ of the academic achievement of the students as evaluated by the Grade Point Average (GPA) of the students. Academic anxiety and academic achievement appear to be significantly related; secondly, in terms of academic anxiety, there is a significant difference amongst students with low, moderate, and high academic achievement, according to this study. Students who attain higher levels of academic achievement tend to have lower levels of academic anxiety, and vice versa. The biggest component of academic anxiety among first-year students at Institut Teknologi Bandung is anxiety-engendering mental activity, which implies low student confidence and selfesteem. The outcomes of this study can be used to support PeKa TPB Ministry of KM ITB in developing a character development program for the first-year students.

Keywords: academic self-management; academic anxiety; academic achievement; firstyear students

\section{Introduction}

College transition becomes a definite step in students' academic path, because during this transition phase students are facing circumstances in college that are different from their previous education life in high school (Alipio, 2020). They are entering a larger and broader environment with individuals from more diverse backgrounds, as well as new academic difficulties. Students are entering the phase of being an independent learner that are expected to be more mature and responsible in taking decision for themselves. They are responsible to manage their study without the teachers' supervision (Alipio, 2020).

The students are required to adapt to their new surroundings and responsibilities that encountered during the first-year of college life; nevertheless, (Shiddiq et al., 2020) noted that for many of the first-year students, the transition might be challenging. The

\begin{tabular}{ll}
\hline How to cite: & Afifah, R., \& Pangestu, A. B. (2021) Relationship of Academic Self-Management and Academic \\
& Anxiety Towards Academic Achievement of First Year Students In Institut Teknologi Bandung, \\
& Syntax Idea,3(8), https://doi.org/10.36418/syntax-idea.v6i8.1415 \\
E-ISSN: & $2684-883 X$ \\
Published by: & Ridwan Institute
\end{tabular}


first-year college students often encounter some problems such as anxiety, loneliness, depression, and social withdrawal (Arjanggi \& Kusumaningsih, 2016). Changes in students' social and emotional aspects have a significant impact on their anxiety along with their academic changes (Sharma, 2012).

During the first year of college, there is a noticeable rise in the student's anxiety. (LeBlanc \& Marques, 2019). (Arjanggi \& Kusumaningsih, 2016) explained that majority of the first-year college students experience anxiety symptoms that have impacted their adjustment academically, because of this, these symptoms may be more prevalent in first-year students. This validates the explanation of (Douglass \& Islam, 2009) that several research have indicated that mental illness is greater among first-year university students throughout the world. A student's adjustment ability becomes a significant predictor of his or her academic performance (Shiddiq et al., 2020).

Before choosing and enrolling majors at Institut Teknologi Bandung (ITB), firstyear students must go through the Tahap Persiapan Bersama (TPB) phase, which is a step of equalizing the fundamental knowledge based on their faculty, which will then be studied more in the department later. The first-year students at ITB are usually referred as the TPB students.

There is no direct self-development institution for the ITB first-year students, since the self-development institution such as the department student association (Himpunan Mahasiswa Jurusan) belongs to the senior year students that already become the part of the department. During the first year, ITB students are usually still in the selection stage of the student activity unit, therefore the student activity units cannot be the self-development institution for the ITB first-year students. Based on the condition, Keluarga Mahasiswa (KM) ITB as student cabinet of ITB, has a special ministry that is in charge of first-year students. The ministry is known as Kementrian Pengembangan Karakter TPB (PeKa TPB), or the Ministry of Character Development for First-Year Students. From an interview with the Faculties General Director of the ministry, PeKa TPB is in charge of developing character development programs for TPB students that intended to facilitate them cope with the issues that arise during their first year at ITB. There are several programs designed by PeKa TPB Ministry of KM ITB for the TPB students, such as Ganesha Academy: Pioneer (GAP), Podcast Serial Pendidikan (PSP), and TPB 2020 Executive School. However, the programs continue to focus on student activities, encouraging TPB students to be engaged in student organizations as a method of character development, with just a few programs focusing on the students' mental and emotional growth as a component of surviving in college.

The Peta Awan Survey was undertaken by the PeKa TPB Ministry to examine the characteristics of first-year students at Institut Teknologi Bandung. The findings of the student's characteristic analysis will serve as the basis for developing character development programs for first-year students. The survey was conducted twice, the initial survey was done before the beginning of first semester and the second survey was done after the first semester completed to see the changes in the preferences of the students after studying in ITB for 1 semester. 
Based on the Peta Awan Survey, the first survey revealed that $62.2 \%$ of ITB firstyear students consider themselves to be easily anxious with $17.3 \%$ of the students consider themselves to be extremely easy to feel anxious. The preference is changing after one semester studying in ITB, where the percentage of students that feel easily anxious is increased to $70.3 \%$ with $29 \%$ of them are extremely easy to get anxious. Students prefer to avoid circumstances that are likely to raise their anxiety.

According to the interview with 11 student representatives from various faculties in ITB, 8 out of 11 ITB first-year students perceived that the high academic pressure, loneliness, difficulty in meeting friends due to the pandemic, managing time ability, unsupported surrounding condition for online learning, and even the tuition fee are influencing their level of anxiousness. Some students even stated that mental health concerns were interfering with their studying. (Kementrian Pengembangan Karakter Kabinet "Arunika" KM ITB, 2020). Academic difficulties, loneliness, and sleep disturbances are the characteristics that linked and predicted students' mental health issues, according to (LeBlanc \& Marques, 2019).

The Peta Awan Survey, which indicated a rise in students' anxiety after studying at ITB, has attracted the attention of the PeKa TPB. They attempted to address this issue by establishing the "Bimbel TPB" program, a web-seminar (webinar) discussion based on the Peta Awan Survey's findings on the mutual demands of TPB students. TPB students are supposed to gain insights, tips, and strategies for surviving their first year of college through this program. The themes covered in the Bimbel TPB seminar include academic and social anxiety. However, according to (Hooda \& Saini, 2017), the best method to minimize academic anxiety depends on which academic anxiety components students are encountering.

Academic anxiety (Shakir, 2014) is a mental state of unease faced by students in relation to their studies and academic concerns such as working on academic duties, preparing class projects, and giving presentations (Nasution \& Rola, 2011). According to (Ottens, 1991), there are 4 academic anxiety characteristics, consists of patterns of anxiety-engendering mental activity, misdirected attention, physiological distress, and inappropriate behaviors (Nasution \& Rola, 2011).

According to (Shakir, 2014), academic anxiety until a certain level is necessary to keep students motivated; nevertheless, high levels of academic anxiety might have detrimental effects. It has been discovered that academic anxiety decreases a student's learning skills and prevents great academic success. According to the findings of study performed by (Nadeem, Ali, Maqbool, \& Zaidi, 2012), (Shakir, 2014), and (Vitasari, Wahab, Othman, Herawan, \& Sinnadurai, 2010), academic performance is influenced by the students' academic anxiety.

According to (Nasution \& Rola, 2011), there is a connection between academic self-management and academic anxiety, with students who have high academic anxiety having low self-management. Similar findings were found in (Etiafani \& Listiara, 2015) study, which revealed that students with strong self-regulated learning likely to have less academic anxiety. 
Based on the phenomenon above, researcher aims to analyze the relationship of academic self-management and academic anxiety towards academic achievement of the first-year students in Institut Teknologi Bandung. This research also aims to find out the most common academic anxiety characteristic occurs among the students and to find out whether or not there is a difference in academic anxiety between students with high, moderate, and low academic achievement of the ITB first-year students.

\section{Research Methods}

The research design is started from preliminary study, problem identification, literature review, until finding the conclusion and recommendation. The research design is presented in the figure below:

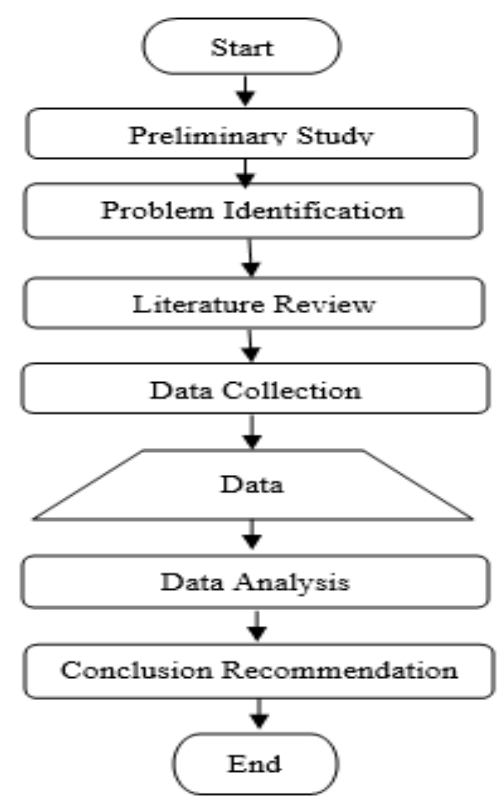

Figure 1 Research Design

This study will employ quantitative approaches in order to discover and establish the link between variables. Quantitative research collects and analyzes numerical data to describe, explain, forecast, or regulate variables and phenomena of interest (Mertler, 2021). The quantitative approach is applied by conducting survey through an online questionnaire. The sample of this study is 111 first-year students in Institut Teknologi Bandung 2020. The random probability sampling is applied in defining the sample of this study.

The questionnaire is adopted from (Dembo \& Seli, 2007) to assess the students' academic self-management, and the questionnaire to assess the students' academic anxiety is adopted from (Ottens, 1991). The Grade Point Average (GPA) of the students from their first and second semester grades will be used to assess the students' academic achievement and will be categorized into 3 categories of high, moderate, and low academic achievement. 
The data collected will be analyze through statistical calculation by using IBM SPSS Statistic Version 24. To assess the relationship of independent variables (X1 and $\mathrm{X} 2$ ) and the dependent variable (Y), the ordinal logistic regression analysis will be applied since the dependent variable of academic achievement is using the ordinal scale with 3 categories. Simple linear regression will be applied to identify the relationship between the independent variables, and One-Way ANOVA will be applied to identify the differences in academic anxiety between 3 categories of academic achievement of the students. The categorization of academic achievement is presented in the table below:

Table 1

Academic Achievement Categorization

\begin{tabular}{cccc}
\hline Label & Variable & GPA & Interpretation \\
\hline \multirow{3}{*}{ AA } & Academic & GPA $<2.50$ & Low \\
\cline { 3 - 4 } & Achievement & $2.50 \leq$ GPA $\geq$ & Moderate \\
\cline { 3 - 4 } & & 3.00 & \\
\hline
\end{tabular}

\section{Results and Discussion}

Table 2

Academic Anxiety Characteristics

\begin{tabular}{ccccc}
\hline $\begin{array}{c}\text { Academic Anxiety } \\
\text { Characteristics }\end{array}$ & N & Minimum & Maximum & Mean \\
\hline $\begin{array}{c}\text { Patterns of Anxiety- } \\
\text { Engendering Mental } \\
\text { Activities }\end{array}$ & 111 & 1 & 5 & 3.843 \\
\hline Misdirected Attention & 111 & 1 & 5 & 3.132 \\
\hline Physiological Distress & 111 & 1 & 5 & 3.108 \\
\hline Inappropriate Behavior & 111 & 1 & 5 & 2.865 \\
\hline
\end{tabular}

The table above shown that patterns of anxiety-engendering mental activity is the most typical academic anxiety characteristic among the ITB first-year students. According to the theory form Ottens (1991), patterns of anxiety-engendering mental activity indicate that students are enduring worries that frequently interfere with their concentration, portraying themselves as less competent academically compared to other students. Worry feelings also discourage them from posing questions since they are afraid of being attacked as incompetent by their classmates. They are also dealing with maladaptive self-dialogue by blaming themselves for making mistakes, and they are struggling to define their self-worth, which leads to poor self-confidence. These circumstances make it difficult for students to achieve well in their learning activities. 
Table 3

Wald Test Result

Parameter Estimates

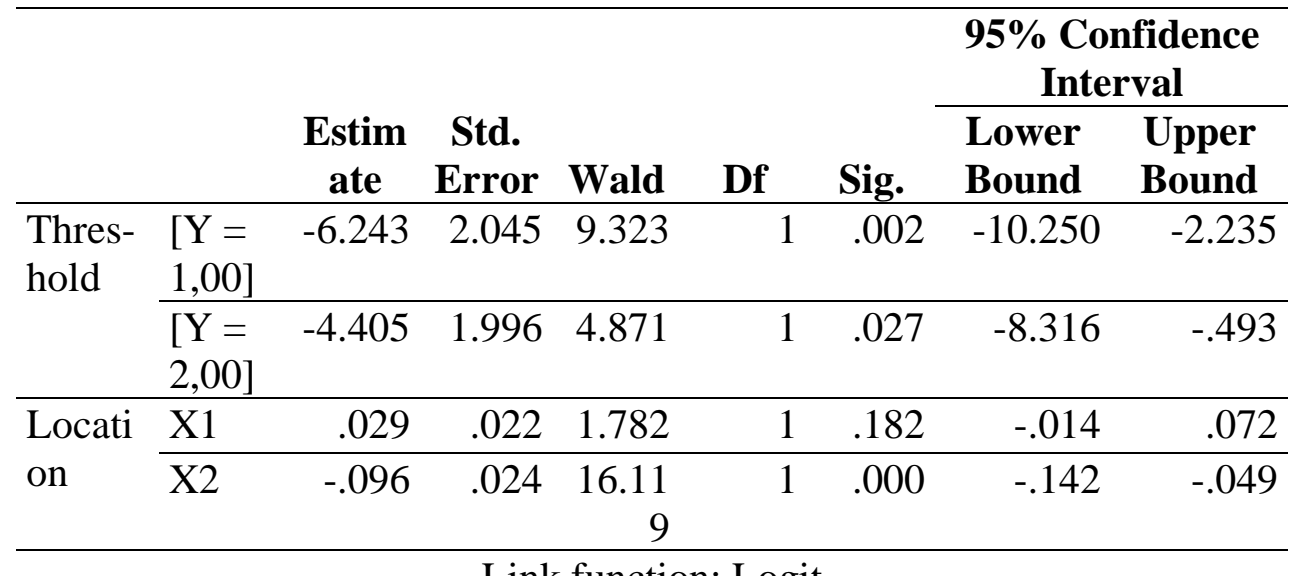

Link function: Logit

According to the ordinal logistic regression analysis, academic self-management (X1) is positively related to academic achievement (Y) among the ITB first-year students; that being said, academic self-management cannot directly foresee the students' academic achievement because there is no significant relationship (p-value 0.182 > 0.05). The implementation of a learning strategy cannot precisely define the academic success that students will accomplish. Students may attain high, moderate, or low levels of achievement despite of which and how many learning techniques they implement throughout their studies. This phenomenon might be caused by differences in the personalities of the students, preferences in learning, expectation pressures, and cognitive ability of the ITB first-year students that varied their motivation in the academic achievement approach (Živčić-Bećirević, Smojver-Ažić and Martinac Dorčić, 2017) (Al-Sheeb, Hamouda, \& Abdella, 2019). According to (Morosanova \& Fomina, 2017), self-regulation indicators are interrelated to a diversity of students' personal attributes, and the amount and attributes of the linkage have a substantial impact on exam performance.

This study also revealed that academic anxiety (X2) has a negative significant relationship with academic achievement $(\mathrm{Y})(\mathrm{p}$-value $0.000<0.05)$ of the ITB first-year students. This means that an increase in academic anxiety is decreasing the students' likelihood of achieving higher academic achievement. This result is consistent with the findings of (Shakir, 2014) study, which discovered an inverse connection between academic anxiety and academic achievement. The logit function calculation for the link between academic anxiety and academic achievement is as follows:

$$
\begin{gathered}
\operatorname{Logit}(P 1)=\log \frac{p 1}{1-p 1}=a 1+\beta^{\prime} X \\
P 1=\frac{\operatorname{Exp}((-6.243)+(-0.096))}{1-\operatorname{Exp}((-6.243)+(-0.096))}=\frac{0.001766}{(1-0.001766)}=0.001769 \\
\operatorname{Logit}(P 1+p 2)=\log \frac{p 1+p 2}{1-p 1-p 2}=a 1+\beta^{\prime} X
\end{gathered}
$$


Relationship of Academic Self-Management and Academic Anxiety Towards Academic Achievement of First Year Students In Institut Teknologi Bandung

$$
\begin{aligned}
P 1+P 2 & =\frac{\operatorname{Exp}((-4.405)+(-0.096))}{1-\operatorname{Exp}((-4.405)+(-0.096))}=\frac{0.011097}{(1-0.011097)}=0.011222 \\
& \text { Therefore, P2 }=0.011222-0.001769=-0.0129
\end{aligned}
$$

The constants and regression coefficient of the academic anxiety variable both are negative, indicating that the independent and dependent variables are inversely linked. Academic achievement starts to decrease when a student's academic anxiety increases. Every $1 \%$ increase in academic anxiety increases the likelihood of a student achieving low academic achievement by $0.00177 \%$ and decreases the likelihood of achieving good academic achievement by $0.0129 \%$.

The relationship of independent variables (X1 \& X2) simultaneously towards the dependent variable is presented in the table below:

Table 4

Coefficient Determination

\begin{tabular}{cc}
\hline \multicolumn{2}{c}{ Pseudo R-Square } \\
\hline Cox and Snell & .175 \\
\hline Nagelkerke & .214 \\
\hline McFadden & .113 \\
\hline \multicolumn{2}{c}{ Link function: Logit. }
\end{tabular}

Academic self-management and academic anxiety both have an impact on ITB first-year students' overall academic achievement by $21.4 \%$. This indicates that strong academic self-management and academic anxiety have a considerable amount in predicting students' academic achievement to the optimum level. Furthermore, the other $78.6 \%$ of the academic achievement is impacted by the variables that could be come from the students' internal or external factors that are not mentioned in this research.

Table 5

Simple Linear Regression Coefficient Result

\begin{tabular}{|c|c|c|c|c|c|c|}
\hline \multirow{2}{*}{\multicolumn{2}{|c|}{ Model }} & \multicolumn{2}{|c|}{$\begin{array}{l}\text { Unstandardized } \\
\text { Coefficients }\end{array}$} & \multirow{2}{*}{$\begin{array}{c}\text { Standardized } \\
\text { Coefficients } \\
\text { Beta } \\
\end{array}$} & \multirow[b]{2}{*}{$\mathbf{t}$} & \multirow[b]{2}{*}{ Sig. } \\
\hline & & B & $\begin{array}{l}\text { Std. } \\
\text { Error }\end{array}$ & & & \\
\hline \multirow[t]{2}{*}{1} & (Constant) & 66.947 & 6.160 & & 10.867 & .000 \\
\hline & $\begin{array}{l}\text { A. Self- } \\
\text { Management }\end{array}$ & -.167 & .102 & -.155 & -1.640 & .104 \\
\hline
\end{tabular}
Coefficients $^{\mathbf{a}}$

a. Dependent Variable: A. Anxiety

Based on the table 5, the academic self-management to academic anxiety regression coefficient is -0.167 , indicating that academic self-management is adversely connected to academic anxiety, with a 1 increase in academic self-management reducing academic anxiety by 0.167 . However, the relationship of both variables is not significant since the significnt value is $0.104(>0.05)$. 
Among the ITB first-year students, having a good academic self-management does not necessarily resulting in have a low academic anxiety. In other words, academic anxiety among first-year Institut Teknologi Bandung students cannot be determined by the student's academic-self management. The result contradicts the findings of (Nasution \& Rola, 2011) who discovered a moderately significant relationship between academic self-management and academic anxiety. Nevertheless, both researches found a negative relationship between academic self-management and academic anxiety. The PeKa TPB Ministry identified the tuition fee, loneliness, lack of peer support, and academic pressure as the top causes of anxiety among the first-year students in ITB.

\section{Table 6}

One-Way ANOVA Descriptive Result Descriptives

\section{A. Anxiety}

\begin{tabular}{|c|c|c|c|c|c|c|c|c|}
\hline \multicolumn{9}{|c|}{ A. Anxiety } \\
\hline & \multirow[b]{2}{*}{$\mathbf{N}$} & \multirow[b]{2}{*}{ Mean } & \multirow[b]{2}{*}{$\begin{array}{c}\text { Std. } \\
\text { Deviation }\end{array}$} & \multirow[b]{2}{*}{$\begin{array}{l}\text { Std. } \\
\text { Error }\end{array}$} & \multicolumn{2}{|c|}{$\begin{array}{l}95 \% \text { Confidence } \\
\text { Interval for Mean }\end{array}$} & \multirow[b]{2}{*}{$\begin{array}{c}\text { Minimu } \\
\text { m }\end{array}$} & \multirow[b]{2}{*}{$\begin{array}{c}\text { Maximu } \\
\mathbf{m}\end{array}$} \\
\hline & & & & & $\begin{array}{l}\text { Lower } \\
\text { Bound }\end{array}$ & $\begin{array}{l}\text { Upper } \\
\text { Bound }\end{array}$ & & \\
\hline Low & 11 & 67.7883 & 7.29942 & 2.20086 & 62.8845 & 72.6921 & 52.62 & 76.59 \\
\hline Moderate & 28 & 59.5286 & 7.88168 & 1.48950 & 56.4724 & 62.5848 & 42.81 & 76.63 \\
\hline High & 72 & 54.3201 & 10.03721 & 1.18290 & 51.9614 & 56.6787 & 28.82 & 74.89 \\
\hline Total & 111 & 56.9686 & 10.15305 & .96369 & 55.0588 & 58.8784 & 28.82 & 76.63 \\
\hline
\end{tabular}

The mean scores in the table above show that the lower the academic anxiety, the higher the academic achievement. Academic anxiety is higher among students with lower academic achievement than those with higher achievement.

Table 7

One-Way ANOVA Result

ANOVA

\begin{tabular}{|c|c|c|c|c|c|}
\hline \multicolumn{6}{|c|}{ A. Anxiety } \\
\hline & $\begin{array}{l}\text { Sum of } \\
\text { Squares }\end{array}$ & Df & $\begin{array}{l}\text { Mean } \\
\text { Square }\end{array}$ & $\mathbf{F}$ & Sig. \\
\hline Between Groups & 1976.280 & 2 & 988.140 & 11.398 & .000 \\
\hline Within Groups & 9363.015 & 108 & 86.695 & & \\
\hline Total & 11339.295 & 110 & & & \\
\hline
\end{tabular}

The significant value in the table above is $0.000<(0.05)$, reflecting a significant difference in academic anxiety between students with low, moderate, and high academic achievement. The students with higher academic anxiety achieve lower in their academic because they have a poorer capability to manage their attention span, focus, memory, and managing distraction (Mirawdali, Morrissey and Ball, 2018) (Jannata and Nur'aeni, 2020). According to (Adesola \& Li, 2018), anxiety is one of the primary emotions related with students' academic performance. 
Relationship of Academic Self-Management and Academic Anxiety Towards Academic Achievement of First Year Students In Institut Teknologi Bandung

\section{Conclusion}

Academic anxiety is most prevalent among first-year college students, and it can have a negative impact on their academic achievement. Academic anxiety, at a certain amount, can enhance students' motivation; nevertheless, excessive academic anxiety has a detrimental impact on students' performance. Academic self-management, in addition to academic anxiety, plays a supportive role in shaping a student's academic achievement. 


\section{BIBLIOGRAFI}

Adesola, Shakirat Abimbola, \& Li, Yongmin. (2018). The relationship between selfregulation, self-efficacy, test anxiety and motivation. International Journal of Information and Education Technology, 8(10), 759-763.Google Scholar

Al-Sheeb, Bothaina A., Hamouda, A. M., \& Abdella, Galal M. (2019). Modeling of student academic achievement in engineering education using cognitive and noncognitive factors. Journal of Applied Research in Higher Education, 11(2), 178198. Google Scholar

Alipio, Mark. (2020). Adjustment to college and academic performance: Insights from Filipino college freshmen in an allied health science course. (January). Google Scholar

Arjanggi, Ruseno, \& Kusumaningsih, Luh Putu S. (2016). College Adjustment of First Year Students: The Role of Social Anxiety. Journal of Educational, Health and Community Psychology, 5(1), 30. Google Scholar

Dembo, Myron H., \& Seli, Helena. (2007). Academic Self-Management. In Motivation and Learning Strategies for College Success: A Self-Management Approach (3rd ed., pp. 3-28). New York: Lawrence Erlbaum Associates, Incorporated. Google Scholar

Douglass, Libbie, \& Islam, Mir Rabiul. (2009). Emotional wellbeing of first year university students: Critical for determining future academic success . First Year in Higher Education Conference, 1-10. Google Scholar

Etiafani, Etiafani, \& Listiara, Anita. (2015). Self-Regulated Learning dan kecemasan akademik pada siswa SMK. Jurnal Empati, 4(4), 144-149. Google Scholar

Hooda, Madhuri, \& Saini, Anu. (2017). Academic Anxiety: An Overview. Educational Quest: An Int. J. of Education and Applied Social Science, 8(3), 807-810. Google Scholar

Jannata, Ainun Hasri, \& Nur'aeni. (2020). Academic Anxiety In Students: A Systematic Review. Future Psychology Interaction of Human Behavior, Culture, and Technology to Create Society 5.0, (2015). Google Scholar

Kementrian Pengembangan Karakter Kabinet "Arunika” KM ITB. (2020). Dokumen Analisis Karakteristik TPB 2020.

LeBlanc, Nicole, \& Marques, Luana. (2019). Anxiety in college: What we know and how to cope - Harvard Health Blog - Harvard Health Publishing. Google Scholar

Mertler, Craig A. (2021). Introduction to educational research. Sage publications. Google Scholar

Mirawdali, Shangal, Morrissey, Hana, \& Ball, Patrick. (2018). Academic anxiety and its effects on academic performance. International Journal of Current Research, 
Relationship of Academic Self-Management and Academic Anxiety Towards Academic Achievement of First Year Students In Institut Teknologi Bandung

10(6), 70017-70026. Google Scholar

Morosanova, V. I., \& Fomina, T. G. (2017). Self-regulation as a Mediator in the Relationship between Anxiety and Academic Examination Performance. ProcediaSocial and Behavioral Sciences, 237, 1066-1070. Google Scholar

Nadeem, Mohammad, Ali, Akhtar, Maqbool, Saira, \& Zaidi, Syeda Uzma. (2012). Impact of Anxiety on the Academic Achievement of Students Having Different Mental Abilities at University level in Bahawalpur (Southern Punjab) Pakistan. International Online Journal of Educational Sciences, 4(3), 519-528. Google Scholar

Nasution, Liza Harlini, \& Rola, Fasti. (2011). Hubungan Antara Kecemasan Akademik Dengan Academic Self Management Pada Siswa Sma Kelas X Unggulan. Jurnal Psikologi Universitas Sumatra Utara. Google Scholar

Ottens, Allen J. (1991). Is Academic Anxiety a Problem for You? In Coping with Academic Anxiety (pp. 1-13). The Rosen Publishing Group. Google Scholar

Shakir, Mohd. (2014). Academic Anxiety as a Correlate of Academic Achievement. Journal of Education and Practice, 5(10), 29-37. Google Scholar

Sharma, Bharti. (2012). Adjustment and Emotional Maturity Among First Year College Students. Pakistan Journal of Social and Clinical Psychology, 9(3), 32-37. Google Scholar

Shiddiq, Muhammad Imam, Fitra, Malika A., Patricia, Ruth, Afriani, Damara I., Bahar, Fironika A., \& Malay, Elok D. (2020). Social Support is Positively Correlated With College Adjustment in First-Year Students. Advances in Social Science, Education and Humanities Research, 494(Iciap 2019), 549-558. Google Scholar

Vitasari, Prima, Wahab, Muhammad Nubli Abdul, Othman, Ahmad, Herawan, Tutut, \& Sinnadurai, Suriya Kumar. (2010). The relationship between study anxiety and academic performance among engineering students. Procedia - Social and Behavioral Sciences, 8(5), 490-497. Google Scholar

Živčić-Bećirević, Ivanka, Smojver-Ažić, Sanja, \& Martinac Dorčić, Tamara. (2017). Predictors of University Students' Academic Achievement: Journal for General Social Issues, 26(4). Google Scholar

Copyright holder:

Rika Afifah (2021)

First publication right:

Syntax Idea

This article is licensed under:

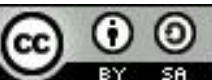

